\section{A Construção da autoridade entre os donos de barco no Aventureiro, Ilha Grande - RJ: uma etnografia das relações de poder}

Recebido:

18/01/09

Aprovado:

20/07/2010

1. Professor Adjunto da Universidade Federal de Mato Grosso do Sul, Campus de Corumbá.

E-mail:

guvillela75@ ig.com.br
Resumo: Este artigo propõe analisar a articulação entre as esferas de poder local e o poder público, a partir de uma descrição etnográfica da organização social e de como, nesta, se estrutura a autoridade política local. Nesse processo de construção da autoridade local, na praia do Aventureiro, Ilha Grande - RJ, o poder político e a autoridade legitimada pelos moradores estão diretamente ligados à posse dos barcos e dos campings mais prósperos. Os donos de barco no Aventureiro assumem, nesse contexto, o papel de representantes legítimos do povoado na negociação com órgãos da Prefeitura e do Estado, na defesa dos direitos dos moradores, assumindo um papel de representação da organização doméstica (em famílias e grupos vicinais) nas relações políticas com o Estado. Palavras-chave: Poder Local, Conflito Ambiental, Turismo, Mudança Social, Barcos.

$\mathrm{N}$ a praia do Aventureiro, observamos um cenário de rápidas mudanças sociais trazidas pela desativação da penitenciária, na Ilha Grande, em 1994, pela implantação da escola de ensino médio, na praia vizinha do Provetá, no ano 2000, passando pelo cotidiano dos moradores, que vieram a conviver com a nova temporalidade da atividade turística, que alterna períodos de alta temporada com os períodos de baixa temporada. Além disso, a partir da explosão turística, de 1994 em diante, os moradores abandonaram progressivamente o trabalho na pesca embarcada ${ }^{2}$ e na agricultura de subsistência para viver quase que completamente dos campings em seus terrenos (poucos moradores ainda trabalham empregados em barcos de pesca e algumas famílias ainda mantém as atividades de agricultura, como renda complementar). No contexto político e jurídico, o povoado do Aventureiro passou a fazer parte de uma Unidade de Conservação desde o ano de 1981, no caso, uma Reserva Biológica, que é a unidade mais restritiva quanto à presença humana. Entre suas principais consequências, destacamos a prática da tutela e controle da própria população que permaneceu no interior da Reserva Biológica, em uma situação
2. Modalidade de pesca assalariada em barcos privados, que no litoral do Rio de Janeiro se caracteriza, principalmente, pela pesca da sardinha, em barcos aparelhados com redes, porão com gelo, entre outros mecanismos. Diz-se pesca embarcada, pois os pescadores realizam essa pesca ao longo do mês, embarcados na traineiras (barcos com rede), parando de porto em porto para vender o pescado aos atravessadores. Essa modalidade de pesca se diferencia, nos termos dos próprios moradores do Aventureiro, da pesca realizada em canoas próximas à costa, para suprimento das famílias e, atualmente, dos campings. 
3. Destaco que este artigo é fruto de minhas pesquisas realizadas entre os anos de 2002 e 2008. Desde então, aconteceram mudanças significativas no governo do estado do Rio de Janeiro e que tiveram impacto direto na organização e atuação dos órgãos ambientais fluminenses, assim como para a população do Aventureiro. A FEEMA (Fundação Estadual de Engenharia do Meio Ambiente) citada neste artigo foi extinta, entrando em seu lugar o INEA (Instituto Estadual do Ambiente), criado através da Lei no 5.101, de 04 de outubro de 2007. O novo instituto, instalado em 12 de janeiro de 2009, unifica e amplia a ação dos três órgãos ambientais vinculados à Secretaria de Estado do Ambiente (SEA): a Fundação Estadual de Engenharia e Meio Ambiente (Feema), a Superintendência Estadual de Rios e Lagoas (Serla) e o Instituto Estadual de Florestas (IEF). de ilegalidade, e que se tornou um objeto de administração por parte do Estado (ver COSTA 2004, 2008). Sendo assim, observamos que essa situação jurídica específica favoreceu, por um lado, um conjunto de práticas tutelares de dominação sobre a população por parte do órgão ambiental e, por outro lado, acabou protegendo a praia da intensa especulação imobiliária, possibilitando, não apenas a permanência dos moradores no Aventureiro, mas também sua gestão do negócio do turismo, ao contrário das demais praias da Ilha Grande, em que o turismo é administrado pelo grande capital ou por empresários vindos de outras localidades (COSTA, 2008)3. Este artigo não tratará das complexas e conflituosas relações que se estabeleceram entre o órgão ambiental e a população do Aventureiro, abordadas em outros artigos (COSTA 2010a, 2010b), detendo-se em uma descrição etnográfica da organização social e como nesta se estruturou a autoridade política local, apontando apenas incidentalmente às questões da relação dessa autoridade local com o Estado.

Na praia do Aventureiro vivem cerca de cem pessoas, que estão distribuídas em pouco mais de trinta casas. Em geral, as casas dos membros de uma mesma família nuclear se distribuem ao redor da casa dos pais nos terrenos contíguos. Um morador só podia, na época da pesquisa, construir sua própria moradia com autorização da FEEMA (Fundação Estadual de Engenharia do Meio Ambiente), quando se casa e constitui sua própria família, em um acordo tácito entre os próprios moradores e os funcionários do órgão ambiental. Em função das proibições da lei ambiental, que atuam ali desde a criação da Reserva Biológica Estadual da Praia do Sul, no ano de 1981, percebe-se que a proibição de construir novas moradias fez com que as casas habitadas tenham todos os seus cômodos ocupados por moradores, em uma situação de superlotação de algumas casas. As casas que possuem terrenos têm também maior área para os campings e, em geral, pertencem às famílias mais prósperas, que podem abrigar mais turistas nas temporadas. Diante dessa nova atividade econômica, houve uma alteração na construção e manutenção das lideranças locais e na questão da autoridade entre os moradores do Aventureiro. Essa alteração ocorreu, principalmente, a partir de duas posições de prestígio e poder que surgiram a partir dos ganhos econômicos com o turismo e com a atividade de camping realizada nos terrenos das famílias: os donos de barco e os donos de camping. Em geral, como veremos, os donos de camping mais bem sucedidos puderam se capitalizar e comprar barcos para o transporte de pessoas e material, aumentando as possibilidades de deslocamento dos moradores para o continente. Os moradores como empreendedores (BARTH, 1972), por sua vez, obtiveram dinheiro suficiente para erguer casas de alvenaria, aumentando as oportunidades para suas famílias permanecerem no local, havendo até a atração de antigos moradores, que voltaram a viver nas terras de suas famílias (caracterizando um movimento inverso, pois, se, no passado, saíram da Praia do Aventureiro para morar em 
um centro urbano, em busca de trabalho, hoje retornam, pela falta de oportunidades na cidade, para o local de nascimento e onde passaram a infância e juventude). É nesse processo, também, que as famílias tendem a concentrar-se cada vez mais sobre si mesmas, modificando um quadro preexistente de ajuda mútua (mutirão, arrasto coletivo de tainha e compartilhamento das casas de farinha), que perderam sua importância na organização social. Com o aumento da renda, as famílias passaram a comprar não só material de construção, como comidas industrializadas, eletrodomésticos, geradores de energia elétrica a óleo diesel e até lanchas a motor. Uma nova forma de competição entre elas se estabeleceu, na qual esses objetos adquiridos com o dinheiro do turismo passaram a representar status e a dar prestígio a seus proprietários. Se, no trabalho de Vilaça e Maia (1988) e em conversas no local, pude perceber que a roça constituía-se como a principal atividade formadora das famílias em um passado recente, hoje são os terrenos de camping. O prestígio da pesca, e dos bons pescadores, também passou a ser atribuído aos bons administradores de camping e que ganham mais dinheiro. Em muitas conversas, os moradores "pais de família", afirmavam estar muito satisfeitos por não depender mais dos donos de barco de pesca (patrões da pesca), de não ter mais que pescar em alto mar, longe da família, e por possuírem o próprio negócio.

A posse de um barco, como analisaremos a seguir, é a principal fonte de poder no povoado do Aventureiro, já que, ao oferecer caronas, o dono de barco se torna uma espécie de credor moral, mantendo os demais moradores sob sua esfera de prestígio ao lhe deverem obrigações sociais. No período em que realizei a pesquisa, entre os anos de 2002 e 2008, pude acompanhar a compra e aquisição de alguns barcos e qual o sentido dessas aquisições para a a legitimação de novas autoridades de poder local. Nesse sentido, nos basearemos no Ensaio sobre a Dádiva, de Marcel Mauss (1991), entendendo o caráter obrigatório das relações de dar/receber/retribuir, porém utilizando-o criticamente para compreender as relações de obrigações sociais que se forjam em torno da figura do dono de barco. Nesse sentido, observaremos também as possibilidades de ruptura da "lógica do dom", ou seja, que o "dom" pode permanecer sem contrapartida na prática da vida social, gerando conflitos locais. Assim, entendemos que essa "lógica do dom" não é exercida e praticada de maneira mecânica pelos atores sociais envolvidos e, que, possui complexidades e nuances. É preciso destacar também a dimensão do tempo, em que essa lógica do dar/receber/retribuir obedece a uma sazonalidade, em que as dívidas morais, altamente pessoalizadas, podem ser resolvidas através do pagamento em dinheiro, de maneira impessoal, especialmente na alta temporada turística (BOURDIEU, 2009).

É preciso destacar que a utilização do termo "barco", assim como o de outras embarcações citadas neste artigo, obedecem à classificação local das 
embarcações, como veremos a seguir. Os termos locais que designam as embarcações são os seguintes:

Canoa: em geral feita de um grande pedaço de tronco escavado e pode ser construída por moradores do local. A espécie de árvore mais utilizada na Ilha Grande é o Guapuruvu. As canoas podem ser a motor ou a remos. A maioria das canoas do Aventureiro leva de duas a três pessoas. Mas há uma canoa grande que pode levar até cinco pessoas (a motor).

Bote: pequenas lanchas de fibra a motor. Em geral, os botes são utilizados para funções semelhantes às da canoa, sobretudo na pesca. Leva, no máximo, quatro pessoas.

Lanchinha: O casco não é liso como o do bote, possui sulcos que meIhoram seu desempenho e a tornam mais estável. Quando o tempo está bom, serve de meio de transporte mais rápido do que o barco para Angra dos Reis. Em geral, não leva mais do que quatro pessoas.

Lancha: iates, lanchas grandes, em geral de turistas.

Barco: barcos de madeira, com casario, de 6 a 12 metros de comprimento. É o principal meio de transporte do Aventureiro. Não possui rede de pesca. Em geral esses barcos são construídos em estaleiros do norte fluminense.

Traineira: a traineira é idêntica ao barco, mas é aparelhada com equipamento de pesca de rede (na verdade, os moradores sabem que a traineira é um tipo de rede e não de embarcação, mas o nome traineira para os barcos em que trabalham embarcados se popularizou e é utilizado por todos).

\section{Os Barcos: o Grande Dom}

Em povoados pequenos, como é o caso do Aventureiro há uma enorme quantidade de informação pessoal à tona entre os indivíduos que a compõem. As fofocas, cujo termo local é "falação", indicam os sinais para uma ética de comportamento local e de vigilância das condutas. Alguns eventos, que ficam falados, se tornam o assunto do momento entre as rodas de conversa na praia ou entre as famílias. Esses assuntos podem girar em torno de traições matrimoniais, compra de barcos, namoros, obras nos terrenos, ou mesmo calúnias e difamações, e mobilizam, direta ou indiretamente, todas as famílias do Aventureiro e, dependendo da situação, as opiniões e posicionamentos pessoais serão levados em 
conta e poderão ser cobrados pelas pessoas envolvidas em algum momento.

Assim, de uma forma ou de outra as famílias e pessoas são julgadas umas pelas outras e as opiniões emitidas em público, inevitavelmente, chegarão aos ouvidos das pessoas. Como bem colocou um morador do Aventureiro, a respeito desse assunto, afirmando que é preciso ficar bem com os outros moradores, pois "você depois de morto precisa de pelo menos dois pra cavar sua cova e mais quatro pra carregar seu caixão". Sendo assim, é muito comum que existam as pequenas desavenças e rusgas, que indicam que uma pessoa "está de mal com outra", sendo que, em muitas ocasiões, são rivalidades e desavenças mais antigas que estão em jogo e esses assuntos momentâneos acabam por reatualizar essas situações.

As sanções pelas opiniões emitidas na "falação" podem se efetuar de diversas maneiras, desde não dar mais carona no barco, no caso da pessoa envolvida ser proprietária de uma embarcação, passando pela proibição de frequentar um bar, até, simplesmente, chegar a ponto de um não falar mais com o outro, embora estejam sempre se cruzando na praia, no cais, em virtude do espaço reduzido em que vivem no Aventureiro. Os eventos mais graves e mobilizantes acabam tornando explícitas as incompatibilidades pessoais e antipatias, que adquirem uma razão ou pretexto para se manifestarem. É importante destacar que as relações pessoais e de parentesco se ampliam para a praia vizinha do Provetá e um caso qualquer acaba sendo "falado" por lá também, tornando-se um assunto partilhado nos dois locais, o que amplia a esfera de reputação de uma pessoa, de modo que a possível vergonha ou desonra pode se tornar um problema ainda maior, no caso dessas fofocas.

O que os moradores chamam de "falação" tem também outra importância social, que não é apenas o controle, coerção e criação de um código de conduta, mas de circulação e troca de informações através da Ilha Grande. Essa circulação das notícias no boca-a-boca, nos cais de Angra dos Reis, do Provetá e de outras praias é muito eficaz e, rapidamente, as notícias correm pelas praias da Ilha Grande e comunicam desde o falecimento de alguém, até a compra de barcos, acidentes ou simples recados. Inclusive, essa forma de comunicação era muito importante no tempo da penitenciária, para alertar sobre a fuga de presos. Destaco que, até a época de minha pesquisa, essa era uma das únicas formas de comunicação, já que os celulares, no Aventureiro, por exemplo, pegavam mal, e os rádios, em geral, servem para comunicação com os barcos. Mesmo as informações recebidas pelo rádio se propagam, em seguida, no boca a boca. É claro que, nesse contexto, os assuntos da vida alheia chegam aos ouvidos uns dos outros de forma muito rápida.

O evento social que mais movimenta os assuntos, ou seja, a "falação", nos 
termos do Aventureiro, é a carona nos barcos. O ato de pedir carona a um dono de barco é significativo para compreender como é exercida a sua autoridade e ilustra como ocorre a construção social da autoridade no Aventureiro. Em primeiro lugar, circula a notícia de que tal barco vai partir para Angra, em tal dia. A partir daí, o morador que quiser uma carona precisa se dirigir pessoalmente ao dono do barco, em geral em sua residência, e pedir o "dom" que lhe é concedido. É nesse momento e nos agradecimentos no cais, ao chegar, que o acordo tácito é firmado entre as pessoas, desencadeando toda uma performance de etiqueta e de atitudes que servem como "pagamento" ao favor concedido. Não é incomum que uma pessoa que esteja de mal com algum proprietário de barco necessite pedir uma carona e, assim, coloca-se em uma posição de inferioridade, naquele momento, pois fica imediatamente com uma dívida moral com o dono do barco. Além disso, a situação é pública, tornando-se assunto nas conversas entre os moradores. Esse exemplo ilustra bem como funcionam as relações de poder no local, sobretudo no universo masculino, pois, em geral, o assunto das caronas é resolvido entre os homens, ainda mais pelo fato de que só os homens dirigem o barco e cuidam de sua manutenção, sendo, de fato, os donos dos barcos.

A quantidade de barcos de uma praia é inversamente proporcional à concentração de poder dos donos de barco; quanto mais barcos, mais pulverizada se encontra a sua autoridade. O caso do Provetá é um exemplo, já que, ali, a grande quantidade de barcos (mesmo que alguns estejam voltados exclusivamente para a pesca) movimenta o trânsito de pessoas entre a ilha e o continente, praticamente todos os dias da semana. $\mathrm{O}$ ato de dar a carona se torna mais parte da rotina e não existe tanto o peso da dívida por parte dos moradores e até mesmo turistas e visitantes podem conseguir uma carona gratuita para a ilha ou viceversa. O caráter mais impessoal da travessia de barcos entre Angra dos Reis e Provetá é percebido, também, no barco de transporte de passageiros, o "Mestre Ernani", serviço, com passagem fixa, instalado pela Prefeitura de Angra dos Reis, em 2005. O transporte passa da esfera pessoal para a esfera pública, com o serviço terceirizado e, assim, como tem um caráter mais impessoal, pelo qual se paga uma passagem, não cria a obrigação para os moradores diante do dono do barco.

O mar, em muitos sentidos, é um obstáculo, uma barreira que precisa ser superada a fim de se alcançar o continente, sobretudo no inverno, época de "mar grosso". A travessia Angra-Aventureiro-Angra é um evento importante no Aventureiro. Mesmo nos dias de hoje, em que cada vez mais barcos fazem o trajeto, os moradores estão sempre atentos à chegada e saída dos barcos, planejam suas idas à Angra e estão sempre informados da saída das embarcações. Hoje, como alguns moradores possuem rádio amador, ou mesmo alguns celulares, já é mais fácil saber também da chegada dos barcos na praia. A compra de um barco é um grande evento no Aventureiro e em toda a Ilha Grande, pois, com ela, 
o morador e sua família adquirem, muito além da mobilidade e da possibilidade de realizar fretes, um status diferenciado e ganham muito prestígio.

Morador: um barco aqui é tudo, né? Minha família não tem barco. É um carro. Vocêtá na cidade precisa de um carro. Os moradores aqui precisam de um barco. É o transporte. Quem ganha com os fretes é o dono do barco e o marinheiro. Em geral, o marinheiro é da família do dono. Já tem gente. Cada família que tem um barco é só da família mesmo que trabalha ali.

Os preços de um barco podem variar de 25 a 60 mil reais, o que caracteriza sua compra como um investimento dos mais importantes na história das famílias do Aventureiro, o que era impensável no passado recente de trabalho na pesca assalariada (embarcada) e da agricultura de subsistência. Mesmo em Angra dos Reis, onde há um número muito maior de pessoas e um porto com centenas de barcos, a chegada de um barco novo, com seu proprietário a bordo, causa grande sensação no cais. Em pouco tempo se torna o assunto nas rodas de conversa entre os pescadores e donos de barco. O barco causa, também, um efeito visível durante todo o tempo em que está atracado, pois pode ser observado, a todo o momento. No Aventureiro, esse fato ganha muito mais importância, pelo fato de ali só haver poucos barcos. Dessa forma, eles são venerados e acabam fazendo parte da paisagem diária no canto direito da praia, afirmando, em todos os momentos, sua presença impossível de dissociar de seu dono.

Além da independência no transporte, da possibilidade de transportar turistas e da economia nos fretes de compras, o que ocorre com o dono de barco, principalmente, é que a pessoa fica livre da obrigação quanto aos demais donos de barco, tornando-se até rival dos mesmos. A situação se inverte e o dono de barco adquire o status de doador e as pessoas que não têm barco passam a lhe dever obrigação. Por outro lado, o dono de barco também é julgado pelos outros, no caso de ser "generoso" ou "jogo duro". Assim, é um símbolo de prestígio pessoal e do sucesso de seu proprietário e, além de ser um objeto útil, se torna um fetiche, que causa inveja e "falação" por parte das pessoas, de modo que o dono passa a ficar sob a pressão de julgamentos e acusações por parte dos demais e precisa reafirmar, a todo o momento, seu status de doador, estando também preso nessa rede de obrigações. Malinowski afirma que:

(...) um barco, seja ele feito de casca de árvore ou de madeira, de ferro ou de aço, vive a vida de seus navegantes e, para o marinheiro, representa mais que um simples pedaço de matéria moldada. Para o nativo, não menos que para o marinheiro branco, o barco está envolto numa atmosfera de romance, construída de tradições e experiências pessoais. É um objeto de culto e admiração, uma coisa viva, que possui personalidade própria. (MALINOWSKI, 1976, p. 91). 
Os nomes de barco podem se tornar lendários na região, como é o caso do "Mestre Ernani" do Provetá. Esse antigo barco de pesca, uma traineira com mais de setenta anos, é um verdadeiro ente, que quase tem vida própria na região. De acordo com um pescador "seu dono até já morreu". Através dessas histórias, percebemos que, na região, todos conhecem a cronologia e história dos barcos, quais foram seus primeiros donos, seus nomes, como foram adquiridos, seus acidentes e histórias pitorescas. Sendo assim, o batismo de um barco, sua pintura, o capricho de sua decoração, são indissociáveis de seu dono. No Aventureiro, quando iniciei minha pesquisa para o Mestrado, em 2002, existiam seis barcos, e acompanhei a compra de mais três embarcações até o final de minha pesquisa de Doutorado, em 2008.

Podemos imaginar a seguinte situação fictícia no Aventureiro, a fim de ilustrar uma situação possível em que se exerce o poder do dono de um barco: um homem da família A é casado com uma mulher da família B. Ambas as famílias são numerosas e possuem membros casados com famílias $C, D$ e E, por exemplo. No caso, a mulher abandona o marido e vai se casar com um amante. Esse ato é visto como uma traição por todos no povoado e a notícia circula, causando a desonra pública do marido. Após o incidente, o pai do homem, que é dono de um barco, em represália, proíbe qualquer membro da família B de andar em seu barco. Essa ação resulta em uma alteração na vida de praticamente todas as famílias do povoado que, de alguma forma, têm elos com a família B. Por exemplo, uma mulher da família $D$, casada com um homem da família $B$, que não teve nenhum envolvimento no episódio da traição, fica impedida pelo pai do homem da família A de andar em seu barco e pegar carona. Essa situação demonstra o peso do "dom", que é a carona de barco (a carona é sempre gratuita, ou pelo menos não é cobrada pelo dono do barco fora da temporada turística, quando são feitos fretes). O poder do dono de barco é exercido nesse momento, em que decide quem pode ou merece andar em seu barco. É em torno dessa questão, então, que os comportamentos são vigiados e controlados por todos, de acordo com as normas locais e, às vezes, pessoais. Quando há um número maior de barcos na praia, como é o caso hoje, do Aventureiro, ficam abertas outras opções de transporte para os moradores, mas se há apenas um ou dois barcos na praia, como era o caso do Aventureiro há mais de dez anos atrás, esse tipo de sanção imposta por um dono de barco adquire um peso muito maior. Com a descentralização de propriedade de barcos, ocorre, portanto, uma divisão do poder local.

De acordo com os moradores, as pessoas devem um respeito ao dono do barco, "não pode ficar falando por trás e no dia seguinte aparecer no cais pra pegar carona". Segundo um morador, "outro dia teve uma moradora que não pôde pegar o barco e ficou lançando praga pro barco afundar, aí não pode". Nos feriados 
e na alta temporada, a dinâmica do transporte local fica totalmente alterada. Em muitas ocasiões, os donos de barco perdem dinheiro se levam os moradores de graça, pois estes estariam tirando o lugar de algum turista, que pagava em torno de $R \$ 25,00$ a passagem, na época em que realizei minhas pesquisas de campo. Como há fiscalização e multas por parte da Capitania dos Portos, os moradores sabem que não podem exceder o limite de capacidade dos barcos. Acontece, porém, que é justamente na alta temporada que os moradores mais precisam ir até Angra dos Reis para renovar o estoque de comida e bebida de seus bares e restaurantes. A única saída para os que não têm barco é fazer um frete pago, "fechando" um barco com um morador, que custava em torno de $\mathrm{R} \$ 300,00$. Caso os moradores, nessa época, vão até a casa de um dono de barco para pedir uma condução, esse "dom" concedido pelo proprietário adquire um peso muito maior no feriado. Por esse motivo, na maioria das vezes, na alta temporada, a carona, chamada de "frete", é paga, tornando-se um serviço. Essas relações de favor seguem, portanto, uma sazonalidade e podem se transformar numa relação estritamente comercial, o que rompe com a "lógica da dádiva", instaurando mecanismos impessoais de pagamento pela carona. A sazonalidade do turismo influencia diretamente nos ciclos de "dom/contra-dom", fazendo com que essa relação não seja apenas moral, mas também instrumental, adquirindo o caráter de serviço contratado, o que por sua vez capitaliza ainda mais os donos de barco.

De acordo com os moradores, com a compra de seu barco, agora quase todos têm uma embarcação a que recorrer, quando é preciso ir até Angra. As famílias, em geral, se agrupam em torno dos barcos de moradores que lhe são mais próximos, seja por parentesco, afinidade ou vizinhança. Nesse ponto, podemos constatar novamente o peso do pedido pessoal, que coloca o que pede em uma situação de dívida. O dono de barco, ao aceitar o pedido, se coloca na posição de doador e, assim, exerce uma dominação pessoal e adquire certo grau de controle sobre sua situação e sobre os moradores. Existe, portanto, uma expectativa de comportamento, uma norma de etiqueta e uma conduta das pessoas diante de um dono de barco. Se for homem, por exemplo, o carona deve ajudar a descarregar o barco. Caso não aja assim, desembarcando no cais e indo direto para casa, fica mal visto pelo dono do barco, que vai pensar duas vezes antes de dar carona de novo. Mesmo as pessoas que venham a observar tal atitude, irão comentar o fato e dar razão à possível represália do dono do barco. Esse comentário do fato que chega aos ouvidos de todos é o que, muitas vezes, fomenta a norma ideal de conduta, que é, assim, incorporada pelos moradores. Alguns moradores afirmam que não cobram, mas que existe muito morador que, sem que nada seja dito, coloque $\mathrm{R} \$$ 50,00 de combustível, um "contra-dom" extremamente eficiente na manutenção daquela relação social.

Presenciei inúmeras vezes o importante evento no Aventureiro, que é a 
chegada de um barco com as compras do camping para o feriado. O processo de descarregar o barco pode demorar algumas horas e, necessariamente, tem que mobilizar um número grande de moradores, em geral os mais jovens, que levam a mercadoria da praia para as casas em carrinhos de mão. Essa mobilização é necessária porque o material para o feriado é comprado em grandes quantidades pelas famílias. Seria quase impossível para qualquer família do Aventureiro retirar tudo sozinha. Dessa forma, os moradores que possuem algum laço de amizade e de obrigação com a família que comprou o material devem ajudar prontamente. Não é preciso chamar, pois todos estão vendo o barco chegar (e que ainda aciona sua buzina) e, além disso, já sabiam que tal pessoa estava em Angra para fazer suas compras. Em geral, a presença dessas pessoas para ajudar a descarregar será cobrada, ainda que de maneira tácita, em algum momento, é preciso haver uma desculpa plausível para que haja o perdão pela ausência no momento em que é preciso fazer força. A mercadoria é retirada dos barcos em canoas e é desembarcada na areia. Os moradores enchem, então, os carrinhos de mão e levam a mercadoria para as casas, o que demanda grande esforço. Essa operação é repetida inúmeras vezes por até cinco ou seis moradores, até que toda a mercadoria esteja guardada em casa. É nesse momento que o dono de barco recebe o auxílio dos moradores que não têm barco. Podemos dizer que os últimos oferecem sua ajuda como contra-presentes, que atualizam a relação com o dono do barco, que, assim, os mantém em alta estima e, sempre que precisarem, terão carona em seu barco. A ajuda no desembarque mantém o acordo tácito entre as partes e, também, os laços sociais vivos entre as pessoas. É bom ressaltar que a ausência na ajuda em algum momento, especialmente no desembarque das compras, quase nunca é cobrada explicitamente, mas a repetição de tal atitude pode acabar por romper o vínculo de proximidade e até uma amizade. Percebi, em várias ocasiões, que ajudar no desembarque das compras pode ser uma estratégia de reaproximação de algum morador que tenha estremecido suas relações com a pessoa que fez as compras. A prestação dessa solidariedade é levada em conta e esse ato, em geral, apazigua qualquer ressentimento ocorrido. Para os mais jovens e solteiros, por exemplo, não é bom ter qualquer rusga com um dono de camping que possua um bar movimentado, pois as noitadas, em que aparecem muitas mulheres de fora, acontecem nesses lugares. Observei casos em que o dono de um bar não permitia a presença de um ou outro morador que tenha cometido um ato visto como de traição ou de "vacilo". Percebi também que, mesmo pessoas que raramente frequentam a casa do morador que realizou as compras, estão ali levando os carrinhos de mão. No caso dos mais jovens, muitas vezes, são seus próprios pais que os obrigam a ajudar, como uma verdadeira norma de etiqueta local. A força desse evento pode ser constatada pela intensa mobilização dos moradores em qualquer desembarque. A pessoa que não cumpre com suas obrigações acabaria se tornando marginalizada pelos demais moradores e teria sua permanência 
e convivência, no Aventureiro, praticamente inviabilizada. Esse tipo de atitude de indiferença com essa norma ocorre mais com pessoas de fora, mas que residem no local, que possuem uma dose relativa de anonimato e liberdade diante dessa teia social do Aventureiro.

A posse de um barco também "prende" seu dono e, ainda, o encarregado da embarcação. É um bem valioso e caro, que demanda muitos cuidados. O negócio dos fretes (transporte de turistas) é lucrativo para muitas famílias que dependem desse trabalho e, dessa maneira, pode até impedir um morador de tentar outro trabalho; como num caso em que um morador gostaria de trabaIhar como marinheiro em lanchas e iates particulares, mas trabalhava no barco de seu pai. Além da situação de ajuda mútua em que esteve envolvido com seu pai, já que este fora o responsável pela compra do barco e, consequentemente, da sua própria renda familiar, havia o apego afetivo ao barco. Em várias ocasiões, esse morador contava de seu dilema e mencionava o afeto pelo barco, de quando chegava o mau tempo e era preciso sair às pressas e levá-lo para a praia da Longa (porto seguro voltado para a baía de Angra dos Reis), onde permanecia por até uma semana se o tempo não melhorasse. Como o Aventureiro não tem um porto seguro e é muito vulnerável às ressacas de inverno, os moradores ficam atentos à previsão do tempo nos telejornais e aos sinais climáticos observáveis, e se a frente fria entra, trazendo o vento sudoeste, é preciso tirar os barcos e permanecer fora do Aventureiro até passar o mau tempo. Abaixo, segue um relato de um morador a esse respeito. É importante destacar que a manutenção e o trabalho de cuidar do barco são incorporados na dívida que os caronas têm com o dono do barco, que é obrigado a cuidar dele e tem custos financeiros e físicos para realizar essa tarefa.

Já gostei e já me arrependi várias vezes de ter comprado esse barco. 0 problema é que o Aventureiro não é protegido pra ancorar os barcos, entendeu? Toda ressaca eu não consigo dormir, quando o tempo vira eu fico acordado de madrugada, saindo com a lanterna pra ver o barco. Por esse lado eu perdi a liberdade que eu tinha. Fico com essa dor de cabeça. Uma vez eu tive que levar o barco pra Angra e dormir nele. Assim que o João Paulo (seu filho) tirar a carteira de mestre Arrais (três meses de curso na Capitania dos Portos) eu vou ficar mais tranquilo. Ele vai poder levar o barco pra Angra e cuidar. Se quiser, ele pode pegar a bicicleta e dormir no barco. Com o barco, também eu quero pagar o aluguel da casa dos moleques em Angra. Posso fazer passeios pra Parnaióca, Lopes Mendes, fazer fretes... e eu não tenho mais que pagar os fretes pra trazer material pro camping.

O barco se torna quase como um membro da família, a que todos se referem pelo nome próprio e é um investimento para o futuro. O barco possui sua 
história particular e essas histórias são conhecidas por todos os moradores, tornando-se indissociável de seus donos. Ao longo do tempo, mudam de donos, mudam de nome e acumulam histórias, ainda mais porque um barco, com boa manutenção pode durar cerca de cem anos. Como dizem os moradores, "dura uma vida inteira".

\section{Os Barcos e o Turismo}

Os fretes de passageiros, no Aventureiro, são um dos principais negócios que se estabeleceram com o turismo. A movimentação de turistas nos feriados de Ano Novo e Carnaval é constante. Em feriados muito cheios, os turistas, inclusive, partem do cais de Angra dos Reis à noite, para chegar no Aventureiro de madrugada. Dessa forma, até as canoas a motor, que podem levar até cinco pessoas, servem como meio de transporte. Esse negócio lucrativo de transporte de passageiros do continente para o Aventureiro atraiu o interesse de muitos donos de barco de Angra dos Reis, do Provetá, do Rio de Janeiro e de outras localidades, o que causa alguns atritos com os moradores locais que possuem barco. Isso ocorre porque um direito local de utilização dos recursos acaba sendo imposto pela população do Aventureiro, seja na questão do que pode e não pode fazer dentro dos limites da Reserva Biológica, seja na questão dos barcos que levam e trazem turistas. A Associação de Moradores e Amigos do Aventureiro (AMAV), buscando regular o transporte, instalou uma cabine de venda de passagens, em que uma ordem de chegada dos barcos é mantida. Das passagens, que custavam em média $R \$ 25,00$ cada uma, são descontados $R \$ 3,00$ : um real para o dono da barraca, um real para a AMAV e um real para a pessoa que trabalha na venda de passagens.

Muitos moradores também disseram que antes da cabine era "cada um por si" e que chegou um ponto em que os donos de barco passavam pela manhã, nos campings, gritando, oferecendo lugar em algum barco, como uma feira de ofertas. Esse conflito entre donos de barco de fora e do Aventureiro é recente, pois a maioria da frota do Aventureiro foi comprada no período de trabalho com o turismo. Os donos de barco moradores do local sentiram-se, então, prejudicados pelos barqueiros de fora e, de alguma forma, conseguiram impor uma parcela de sua vontade. Cada barco que tem sua capacidade esgotada parte do cais do Aventureiro e o próximo entra na fila. A ordem dos barcos, dos donos moradores do Aventureiro pode ser mantida de um feriado para o outro, para que ninguém se sinta prejudicado em um longo prazo. Na alta temporada, os barcos do Aventureiro não dão conta de levar e trazer todos os turistas e é preciso que barcos de Angra dos Reis e do Provetá façam fretes também. O conflito ocorre, principalmente, em feriados pouco movimentados, quando há barcos de 
sobra para levar os turistas. É claro que essa regulação ameniza os conflitos, pois ordena de alguma forma as embarcações, mas, em várias ocasiões, é difícil manter a ordem estabelecida e o dono de barco não se cansa e argumenta (dando justificativas como a de que "eu trouxe essa galera é meu direito levar eles") e acaba conseguindo partir com o barco cheio. Muitos donos de barco podem perder a paciência e não entrar nas querelas, mas, assim, acabam perdendo a posição de seu barco. Por isso, no dia de partida dos feriados, é grande a movimentação em torno da cabine, seja de turistas comprando as passagens, seja dos donos de barco, com sua tripulação, argumentando sobre alguma injustiça cometida na lista de barcos. A argumentação acontece em alto volume, com muita discussão, muitas vezes em tom jocoso também, pois são sempre os mesmos barqueiros que disputam os passageiros.

Como se pode deduzir das informações acima, a compra de um barco, por parte de um morador, altera a ordem local na cabine e a presença de mais um barco pode se tornar uma ameaça ao negócio dos outros barqueiros, pois no momento em que se adquire um barco, seu status cresce no povoado e o dono passa a ter direito de entrar na fila da cabine e de opinar sobre questões de justiça, injustiça e qual a melhor ordem de barcos na fila de espera, por exemplo. Além disso, uma pessoa não é apenas dona de um barco no Aventureiro, mas, na maioria dos casos, é dona de um camping também. E como existem campings mais movimentados que outros, aqueles que são donos dos campings mais movimentados e também dos barcos se veem no direito de transportar os turistas ali acampados. Além da viagem Aventureiro/Angra dos Reis, os donos de barco realizam, cada vez com maior frequência, os passeios, cujos barcos só partem se estiverem cheios, por outras praias da Ilha Grande, como a Parnaióca, Lopes Mendes, Dois Rios e outras. O dono de barco que realiza um passeio passa, então, a último da fila na ordem de barcos da cabine e é de bom tom que aceite essa norma. Porém, não é sempre que aceita, pois, muitas vezes, pude observar que o passeio é visto como um mérito pessoal do dono do barco e de algum tripulante que conseguiu vender o pacote para os turistas.

\section{O papel das embarcações no poder político local}

A partir das entrevistas, podemos construir um histórico recente do papel da autoridade no Aventureiro e sua relação com os barcos ou as canoas a motor do passado. Além de parteira e rezadeira, a moradora chamada D. Angelina (falecida em 2007) foi a dona da primeira e maior canoa de rede a motor. A principal função dessa canoa era a pesca da tainha, que era o mais importante trabalho comunitário e de pesca do Aventureiro, embora servisse para todo tipo de pesca e para o transporte de pessoas também. Sempre que havia uma pescaria, 
do resultado final, metade ficava com D. Angelina, seja em peixes ou em dinheiro. Dessa forma, o dono da canoa se capitalizava ao mesmo tempo em que aumentava seu prestígio junto aos demais, já que, naquele tempo, as pessoas dependiam da canoa a motor tanto para se deslocar quanto para vender seus produtos, seja em Angra dos Reis ou no Provetá. Nesse sentido, o dono da canoa a motor assumia, a seu tempo, um papel e um status semelhante ao do dono de barco dos dias de hoje. Hoje, essa grande canoa foi restaurada por seu filho Sidneis, que a rebatizou como "Lembrança", em homenagem à sua falecida mãe, e repousa na praia como um monumento do passado, em uma espécie de "enterro" simbólico da canoa.

A canoa dava prestígio e poder a seu proprietário e tais atributos estavam concentrados na figura de D. Angelina, pois não havia outras canoas a motor em sua época. D. Angelina pôde comprar sua canoa, o motor e a rede porque herdara outra canoa menor de seu tio e tinha, ainda, algumas economias (havia trabalhado como babá para os filhos do ex-diretor do presídio, em Dois Rios). As canoas ainda têm grande utilidade no Aventureiro, mesmo com o crescente número de barcos, lanchas e botes. A canoa é utilizada para a pesca, com rede de espera e para o transporte da carga dos barcos. Uma rede custava, na época da pesquisa, em torno de $\mathrm{R} \$ 500,00$, de modo que nem todos podiam comprar uma rede nova. Vovô é um dos moradores que sabem fazer as canoas de tronco escavado, mas afirmou que o pessoal já compra os botes de ferro para as mesmas funções. De qualquer forma, é nas canoas que as crianças são iniciadas em sua experiência nos trabalhos no mar. Assim como as crianças no continente brincam de bicicleta, no Aventureiro, é comum vê-las nas canoas. É comum que um pai dê de presente para um filho de 12, 13 anos, uma canoa. A criança, com orgulho, vai batizá-la, pintá-la e escrever seu nome na proa.

Foi apenas na década de 1980 que um morador adquiriu o primeiro barco do Aventureiro. A origem da compra desse barco é curiosa. Foi adquirida a partir da participação de um morador na Segunda Guerra Mundial. Antonio Osório, já falecido, era ex-combatente da 2a Guerra e não havia recebido sua aposentadoria até os anos 1980. Um amigo da família, que frequentava o Aventureiro como turista, cujo pai também era militar, o levou ao Rio de Janeiro e ele pôde conseguir o dinheiro a que tinha direito. Antonio Osório era também funcionário, vigia da FEEMA e, com esses aportes, pôde se tornar o primeiro proprietário de barco no Aventureiro. Assim como a autoridade da dona da canoa a motor se concentrou, primeiro, na figura de D. Angelina, Antônio Osório centralizou a autoridade local em um segundo momento, suplantando não apenas as canoas que ficaram obsoletas diante do barco a motor, mas a autoridade de seus proprietários. Esse morador dispunha também de outros fatores de prestígio, além da posse do barco: sua idade, seu cargo na FEEMA e sua condição de 
ex-combatente da 2a Guerra Mundial. Assim, a canoa capitalizava seu dono, que sempre recebia metade dos frutos da pesca (ainda mais porque contava com uma pequena tripulação); logo em seguida, Antonio Osório entrou em uma sociedade com outro morador, Verte, para fazer seu segundo barco, colocando o capital para o material e o motor, enquanto o sócio entraria com a mão-de-obra e o conhecimento para a construção. Dessa forma, surgiu o segundo barco do Aventureiro: o "Ternura". Verte, mesmo em sociedade, entrou no seleto grupo de moradores que possuíam um barco no Aventureiro. Com seu barco e a incipiente atividade de turismo, pôde abandonar o trabalho nas traineiras (como pescador embarcado) e se dedicar ao próprio negócio e, a partir daí, comprou seu barco "Amanda", porém foi desde o "Ternura" que veio construindo e fortalecendo sua autoridade, de "doador" no local, como demonstra um morador, em sua entrevista:

P: Como foi quando compraram o primeiro barco aqui no Aventureiro? Luis: Foi novidade. Aqui tudo é novidade. Só se comenta aquilo. Aqui é assim: acontece uma novidade, chegou o primeiro gerador, foi do Verte também, só o que comentava era aquilo. Todo mundo se acabando pra arrumar o dinheiro pra comprar um. O Mário comprou, aí todo mundo comprou e ninguém fala mais isso de gerador. $\mathrm{O}$ barco, a mesma coisa. O Verte, qualquer pessoa que precisasse, ele levava. Eu devo muita obrigação a ele. Não é porque eu tenho um barco, hoje em dia, que eu vou chegar, "ah, eu não preciso, o Verte que se dane, eu tenho um barco maior do que o dele". Não, eu que devo obrigação a ele, tanto a ele como ao Sidneis. Aos dois. Eu com esses filhos, tudo pequenininho, dormindo aqui. Aí o barquinho andava pouco, tinha que sair de madrugada pra Angra. Eu falava, "vai pra Angra?", "vou", de manhã cedinho, às vezes eu perdia a hora de madrugada e ele gritava "ô Luis, Luis!”... quantas vezes o Verte vinha aí com a lanterninha, "vamos pra Angra, vamos agora, ta na hora, vamos embora". Vinha me chamar.

Ao passar dos anos, os moradores foram comprando seus barcos com o dinheiro do turismo e, hoje, praticamente todos os ramos familiares têm acesso direto aos barcos e a autoridade se fragmentou, ocorrendo uma divisão do poder local, que deixou de ficar concentrado em poucas pessoas, como no tempo de Antônio Osório e de Verte. O papel de "doador" se dividiu em pelo menos nove proprietários de barco, descentralizando a autoridade no local, pois o morador sempre pode recorrer a uma pessoa mais próxima para conseguir uma carona para o continente, sem ter que se sujeitar a um dono de barco com o qual não tenha simpatia e que Ihe cobraria com mais intensidade os favores.

Os donos de barco têm um papel fundamental na reorganização do espaço 
dos campings e nas negociações para reabertura dos mesmos, no Aventureiro, no período pós-proibição da atividade turística, no Carnaval de 2006 (ver COSTA, 2008). Além disso, os donos de barco também são os grandes interessados no negócio dos campings e dos fretes de turistas (em geral, os novos barcos foram comprados através de seus campings e bares) e são os mais assíduos nas reuniões com o poder público, assumindo o papel de líderes políticos do povoado, na negociação com a Prefeitura de Angra dos Reis e com a FEEMA, na luta pelos direitos dos moradores. Observei que a participação dos donos de barco nas negociações e reuniões deu-se não apenas pelo interesse econômico imediato e pelo fato de terem comprado um bem valioso como um barco (que representava um capital imobilizado diante da proibição dos campings), mas a voz ativa nas reuniões era legitimada pelos demais moradores, que mantinham um respeito diante da condição de dívida que tinham com os donos de barco. Esse status e prestígio é que os colocou na situação de representantes oficiais dos moradores, em conjunto com o presidente da Associação de Moradores, que era visto como um representante oficial mais pelo poder público, do que pelos próprios moradores. A própria capacidade de carga (número de turistas) a ser negociada com esses órgãos passa pelos proprietários de barcos. Em geral, eles buscam o controle sobre o frete de passageiros, reivindicando que o número de barcos já é suficiente para levar e trazer os turistas dentro do limite a ser estipulado, seja ele qual for. Os moradores afirmam que os barqueiros de Angra dos Reis, Provetá e até Rio de Janeiro não saberiam respeitar os limites definidos. Esses barqueiros não operariam sob a ética local que visa resguardar os moradores das sanções legais, no caso do número de turistas extrapolar os limites negociados. Para os moradores, esse é um ponto fundamental para que o limite venha a ser respeitado, pois os barqueiros de fora, de acordo com os moradores, estariam mais preocupados com o lucro imediato dos fretes, sem se preocupar com os moradores do Aventureiro.

Esse é um breve histórico do processo de construção e legitimação da autoridade no Aventureiro, que se dá a partir da posse de embarcações, desde as canoas a motor até os barcos; desde a época do relativo isolamento e da grande distância do continente até a nova era de turistas e trânsito mais intenso. Nesse processo, percebemos que houve a descentralização da autoridade, que conta com um número maior de barcos a que as famílias podem recorrer para se locomover e fazer compras. Além disso, o Aventureiro passou a conviver, também, com a concorrência externa de donos de barco do continente e de outras praias da Ilha Grande. Ao longo da pesquisa, foi possível constatar o peso que os donos de barco possuem na organização social atual do Aventureiro, seja através de sua afirmação enquanto transporte legítimo e autorizado, através da cabine de barcos, que vende as passagens, seja nas tomadas de decisão e nas negociações com o poder público em torno da legalização dos campings e dos fretes de 
turistas.

Com a reorganização do espaço no Aventureiro, com a abertura dos campings nos terrenos das famílias, teve início um processo de diferenciação social entre as famílias e o aumento das possibilidades de ascensão social das mesmas. 0 sucesso de um camping depende não só de sua localização na praia, mas dos investimentos e das atitudes pessoais dos membros das famílias, além de sua capacidade de apreensão e interação social com o estilo de vida dos turistas (BAR$\mathrm{TH}, 1972$ ). Neste artigo, entretanto, destaco que os campings se tornaram, junto da posse dos barcos, em mais um fato social que confere autoridade e prestígio aos moradores que são os donos de campings mais prósperos. Essas categorias "dono de barco" e "dono de camping" substituem antigas posições de prestígio de um passado recente, como "proprietário de uma roça grande", "pescador embarcado". Além disso, a compra do barco está condicionada aos ganhos com o turismo e, assim, existe uma relação estreita entre o sucesso do camping, a compra de um barco e o aumento da autoridade de alguns moradores.

\section{Considerações Finais}

Essa diferenciação social entre os donos de camping engloba, assim como os barcos, a separação entre as famílias, pois o camping e o barco não pertencem somente ao chefe de família, ao homem da casa, mas a todos os membros. Essas unidades de trabalho familiar se tornaram motivo de discórdia no Aventureiro, sobretudo quando há a percepção de que alguns ganham mais do que outros. As diferenças nos ganhos não dependem apenas da localização privilegiada de alguns terrenos, mas do grau de interação entre os membros das famílias e os turistas, assim como do investimento que é feito, tanto na infraestrutura dos campings, quanto em sua decoração. Nesse sentido, entra a questão do mérito e capacidade de cada família em obter sucesso, fator que é sempre motivo de discussão entre os moradores. Destaco um desses momentos quando houve o acordo firmado, entre os órgãos públicos e os moradores, no final de 2006, que estabelecia a capacidade de carga (ou seja, o número de visitantes no Aventureiro). O número de visitantes, que ficou estabelecido em 560 turistas por dia, causou discussões não só com os órgãos do governo, mas entre as famílias. Os campings menos favorecidos temiam ficar sem nenhum turista, enquanto os campings mais bem sucedidos tenderiam a captar o maior número de visitantes. Sendo assim, houve um acordo interno entre as famílias, que respeitava a infraestrutura investida em cada camping, já que não seria justo que aqueles que mais investiram perdessem seus hóspedes, assim como também não seria justo que os campings menores perdessem sua frequência habitual e, assim, perdessem sua capacidade de reinvestimento e de 
crescimento. Nesse momento do acordo percebi que os donos dos campings mais prósperos, ainda que a contra gosto, cederam diante dos argumentos dos donos de campings menores ou localizados em pontos menos favorecidos, e se colocaram em uma posição de doadores, fazendo uma "concessão" de alguns hóspedes para outras famílias. Nessas negociações, tanto os donos de barco, quanto os donos de campings mais prósperos (que são basicamente as mesmas pessoas) tomaram a frente nas decisões, assumindo o papel de líderes no Aventureiro, tanto por sua condição financeira privilegiada como pela posição de doadores, tanto das caronas nos barcos, quanto na concessão de turistas e de espaço para os demais moradores. Embora minha pesquisa tenha terminado no início do ano de 2007, acompanhei os desdobramentos das negociações jurídicas a respeito da permanência dos moradores na praia do Aventureiro e da recategorização da Reserva Biológica Estadual da Praia do Sul (que deve se tornar outra Unidade de conservação compatível com a presença humana), ao longo do ano de 2007 e de 2009. Entre os fatores que me chamaram a atenção e que corroboram essas hipóteses relativas à construção social da autoridade no Aventureiro, que ocorre em torno dos donos de barco e dos donos de camping - em geral, as mesmas pessoas - foi o fato de Luís ter assumido o posto de presidente da Associação de Moradores, no ano de 2007. Podemos afirmar que Luís e sua família são os proprietários do camping mais bem sucedido do Aventureiro, além de serem os donos do maior barco da praia, o "Rei Mateus". Sendo assim, percebemos que a autoridade se concentrou, tanto implicitamente (como dono de camping e de barco) quanto explicitamente (como presidente da AMAV) em torno da sua figura, em um momento crítico da história do Aventureiro, quando a questão da terra estava sendo renegociada, em novos termos, com os órgãos ambientais. Essa é uma questão importante, ainda, para compreendermos de que maneira o poder dos moradores se impôs junto ao funcionário externo da FEEMA, que passou a viver no Aventureiro, no posto desse órgão ambiental - já que a FEEMA não dispõe de barco próprio para o transporte do funcionário - e, assim, dependia dos moradores do Aventureiro para ir e vir da Ilha Grande, tornando-se também um devedor, nesse sentido, dos donos de barco. Além disso, foi possível constatar o peso que os donos de barco possuem na organização social atual do Aventureiro, seja através de sua afirmação enquanto transporte legítimo e autorizado para os turistas, através da cabine de barcos, que vende as passagens, seja nas tomadas de decisão e nas negociações com o poder público em torno da legalização dos campings e dos fretes de turistas, em função de seu interesse direto. Essa autoridade dos donos de barco é construída em torno das dívidas morais e das obrigações que os demais moradores lhes devem, ao pegar as caronas de ida e volta para o continente, e assim são forjadas as lideranças políticas, na prática. Nesse sentido, este estudo de caso aponta para algumas questões como a construção e legitimação social de um grupo de moradores que se organizou socialmente e construiu 
- a autoridade nas relações domésticas, a partir de suas atividades sociais. Além disso, podemos compreender de que maneira as autoridades locais se tornaram representantes legitimados em um processo de negociação pela utilização de um território delimitado, articulando suas posições e interesses junto às instâncias de poder mais amplas, sejam elas municipais, estaduais ou federais.

Abstract: This paper proposes, from an ethnographic description of social organization and how it structures the local political authority, to analyze the connections between local power and public administration through the building of local authority at Aventureiro Beach, Ilha Grande, state of Rio de Janeiro. The inhabitants' political power and legitimate authority are connected to the ownership of boats and to the most successful campings. The boat owners take the role of legitimate at the negotiation with the municipality and state, looking after the inhabitants' rights, assuming a role in representing the domestic organization (families and vicinal groups) in political relations with the state. Keywords: Local Power, Environmental Conflict, Tourism, Social Change, Boats.

\section{Referências Bibliográficas}

BARTH, Fredrik (ed.) The Role of Entrepreuner in Social Change in Northern Norway. Bergen: Scandinavian University Books, 1972.

BOURDIEU, Pierre. O Senso Prático. Petrópolis: Vozes, 2009.

COSTA, Gustavo V. L. A população do Aventureiro e a Reserva Biológica Estadual da Praia do Sul: conflitos e disputas sob tutela ambiental. Dissertação de mestrado defendida no PPGAS, MN/UFRJ, 2004.

. O Aventureiro, Ilha Grande-RJ: uma análise de mudança social. Tese de Doutorado defendida no PPGAS, MN/UFRJ, 2008.

- "A entrada do direito na resolução de um conflito ambiental: A gestão personalizada de uma Unidade de Conservação na Praia do Aventureiro (Ilha Grande, RJ)". Dilemas: Revista de Estudos de Conflito e Controle Social, v. 7, 2010a, p. 9-31.

. "O Território Tutelado: o caso do Aventureiro, Ilha Grande-RJ". GEOgraphia (UFF), v. 12, 2010b, p. 108-123.

MALINOWSKI, Bronislaw. Argonautas do Pacífico Ocidental. Um relato do empreendimento e da aventura dos nativos nos arquipélagos da Nova Gunié Melanésia. São Paulo: Editora Abril, 1976. 
MAUSS, Marcel. “Essai sur le don. Forme et raison de l'echange dans les societés archaiques", Sociologie et Anthropologie. Paris, Puf, 1991, p. 145-279. 